\title{
Gender Differences in Business Related Experience amongst Smmes Owners in King Williams Town, South Africa: A Comparative Analysis
}

\author{
Herring Shava \\ Department of Business Management, University of Fort Hare, P. Bag X1314, Alice, 5700. \\ Email: hshshava@gmail.com \\ Ellen Chenesai Rungani
}

Department of Business Management, University of Fort Hare, P. Bag X1314, Alice, 5700.

\section{Doi:10.5901/mjss.2014.v5n20p2687}

\section{Abstract}

This paper aimed at examining whether or not the level of business related experience conceptualised as managerial, industry and prior-business ownership experience differs across gender amongst SMME owners in King Williams Town, South Africa. Questionnaires were self-administered to 109 respondents (56 male and 53 female-owned SMMEs). Data obtained was statistically analysed by making use of the Chi-Square test to determine whether or not a significant association could be found between gender and the level of business related experience in the selected area of study. The findings revealed that a statistically significant association can be found between gender and the level of management experience as well as in the level of prior-business ownership experience. However, the study's findings further revealed that no statistically significant association could be found between gender and the level of industry experience. On the basis of the findings, it is proposed that private and public firms should therefore set targets for women in senior roles as this would help female employees to acquire managerial and industry experience considered crucial in case they decide to operate their own Small, Medium and/or Micro Enterprises. Further, it is recommend that the business community, government and the community at large should encourage female business owners to work hand in hand with international networks such as the World Association of Women Entrepreneurs (FCEM) that have the potential for transferring knowledge and business related experience between different continents.

Keywords: Managerial experience, Industry experience, Prior business ownership experience.

\section{Introduction}

Individuals with profound managerial, prior business ownership and industry experience can contribute different significant expertise in various business functional areas, more importantly in decision-making. A substantial amount of evidence suggesting that women business owners have the capacity to improve firms' performance economically exists in literature (Catalyst, 2007; London School of Business, 2007a; McKinsey \& Company, 2007). However, despite the availability of this fundamental evidence, the gender gap in business related experience continues to exist in various parts of the globe. Women SMME owners with an extensive amount of such experience continue to play important roles that enable their firms to adapt to an ever-changing marketing environment, through above par contract negotiating skills and other practices such as team building (Organisation for Economic Cooperation and Development (OECD), 2008, p.29).

The OECD $(2008$, p.29) reveals statistics from around the globe that explicitly portrays countries' poor utilisation of human capital in both the public and private sectors. This is largely explained by the fact that in OECD nations, women constitute $40-50 \%$ of the labour force. However, women in top management do not exceed $8 \%$ despite contributing nearly half of the labour force. This negatively affects creativity and innovativeness of SMMEs resulting in poor economic performance of the sector. On the other end, males dominate managerial positions in all OECD countries. According to the Ethical Investment Research Services (EIRIS), (2005), in the OECD it is estimated that only $7 \%$ of the directors for leading firms are women. In the absence of corrective measures to address this gap, this practise will perpetuate the gender gap in business related experience particularly in management.

Gender relates to cultural issues that are shared by the whole community at large. By definition, "gender" refers to involuntary grouping of humanity into "masculine and "feminine" (Oakley, 1972, p.36). Through the passage of time, involuntary grouping of humanity into "masculine" and "feminine" by societies has been practiced as it is being practiced 
today. The difference between these societies however being that of dynamic changes in "normative behaviour" considered as acceptable with regards to a particular group (Synnot, 1993). Within a community, gender is fairly portrayed in a binary "division." The binary "divisions" bring about multiple behavioural perceptions ascribed to the "feminine" and "masculine." The common trend however in societies being that the masculine stands to be more privileged as compared to the feminine, therefore supporting the ranking system of "traits" and "characteristics" (Marlow \& Patton, 2005 p. 720). Globally, studies and policies with the aim of eliminating the perception that the masculine are dominant species have been widely debated and implemented. However, Crannie-Francis et al. (2003) argue that even in this civilised world, men still resemble the upper end and anything that is associated with men is considered the control variable to which all others are compared to.

Literature reviewed suggests that men's "norms and values" outweigh women's. Resultantly, the manner in which women embrace, practice and implement the entrepreneurship concept and other socio-economic activities is more aligned to men's practices. However it does not suggest that women do not have better methods of carrying out business activities successfully. The discussion suggests that the activities which the society chooses to consider are the ones where men dominate, whereas activities undertaken by women are sometimes overlooked (Gutek \& Cohen, 2002). In addition, regardless of women's abilities and industry of choice, their practices in some areas of socio-economic activities are continuously being overlooked and this is manifested in various ways. For example, women compared to men find it hard to secure critical resources to engage fully in entrepreneurship activities. This is mainly influenced by "gendered characterisation" that are undesirable, complicated, and diverse. These characterisations continuously place challenges which women in entrepreneurship and in the labour market find impossible to negotiate leading to gender gap in business outcomes and business related experience (Marlow \& Patton, 2005, p.722).

The focus of this study is to identify the gap in experiences of male and female SMMEs owners which are managerial, prior business ownership and industry conceptualised in this paper as business related experience. Business related experience has been argued as critical resources essential for business success (Powell et al. 2008.) In fact, Zacharakis and Meyer (2000) argue that, management skills and experience are the most frequently used selection criteria of Venture Capitalists. Studies such as Bosma et al. (2004); Sonnentag and Frese, (2002); and Honig, (2001), further argue that certain aspects of human capital, for example, experiences, may play an even larger role in the future because of the constantly increasing knowledge-intensive activities in most work environments. However, Baum and Silverman (2004), argue that the relationship between business related experience and entrepreneurial success across gender is overemphasised. Despite Baum and Silverman's point of view, Harber and Reichel (2007) further emphasise that business related experience constitutes one of the core factors in the entrepreneurial process.

\subsection{Research Objectives}

The paper seeks to:

- Ascertain whether the level of industry experience differs between genders with regards to SMME owners.

- Ascertain whether the level of prior business ownership experience differs between genders with regards to SMME owners.

- Ascertain whether the level of managerial experience differs between genders with regards to SMME owners.

\subsection{Theoretical Framework}

According to Becker (1964), experiences, skills and knowledge that individuals acquire through investments in schooling, on-the-job training, and other types of experience fall under the definition of human capital. This is also supported by Unger et al., (2009, p.342), who declare that human capital variables include education, experience, knowledge, and skills and these have long been argued to be critical resources for success in entrepreneurial firms. Becker (1964) further emphasise that, human capital investments include experiences such as education, work/industry experience and managerial experience that may or may not lead to knowledge as well as skills. Fapohunda (2013, p.37) supports the notion of Unger et al. (2009, p.342) that to entrepreneurs, business related experience such as prior business ownership, entrepreneurial start-up, industry and managerial experience are essential tools necessary for the successful establishment and running of a business enterprise.

The "human capital theory" argues that acquiring of knowledge and experience by individuals enables the enhancement of their cognitive abilities resulting in improved productivity and "efficient potential activity" (Mincer, 1974; Becker, 1964; Schultz, 1959) cited in Honig and Davidson (2003, p.305). In other words, if attractive entrepreneurial opportunities exist in the market, individuals with higher levels of knowledge and experience should be better at 
perceiving them. Honig and Davidson (2003:305) argue that, if such individuals with higher levels of knowledge and experience engage in emerging attractive entrepreneurial opportunities, such individuals should also have superior ability in successfully exploiting the developing opportunities. According to Cassar (2006) given that an individual chooses to pursue entrepreneurial activities; there seem to be a significant relationship between the level of experience and entrepreneurial success. Individuals who have in the past invested more in acquiring relevant entrepreneurial experience are likely to realise higher returns and growth. These individuals are highly motivated and dearly seek satisfying compensation for their investment in experience. On the other hand, individuals who had channelled little resources towards acquiring business related experience, their motivation levels are low and probably their focus as well. Research focussing on entrepreneurship presents various dimensions on how human capital should be able to improve the level of success on each individual entrepreneur (Unger et al. 2009, p.344). Firstly, Shane and Venkatraman (2000) emphasise that "human capital increases the capability of owners to perform the generic entrepreneurial tasks of discovering and exploiting business opportunities." Additionally, human capital affects the business owner's approach and the implementation of business strategies. Secondly, "human capital is positively related to planning and venture strategy, which in turn, positively impacts success" (Frese et al. 2007). Brush et al. (2001) declare that experience play a major role in sourcing "utilitarian resources such as financial capital and can partially compensate a lack of financial capital" which research has identified as a major challenge for many entrepreneurial entities.

\section{Literature Review}

Globally, "gendered characterisations" are dynamic throughout time owing to civilisation. Underlying perceptions relative to the feminine on the other end are either static or rarely at par with the level of civilisation prevailing worldwide (Marlow \& Patton, 2005, p.720). Thus, the manner in which women were being described during the error of the philosopher Aristotle in Ancient Greece is still evident in some communities today. Women were labelled weak, cautious and good at domestic activities, while men were considered strong and adventurous (Tradennick, 1968-1969). Lister (2003, p.71) laments that in some societies Aristotle's description of women is still the order of the day though little adjusted. These communities present men as "rational, independent, active and strong." On the other hand, women are however largely associated with the comfort of homes. Gutek and Cohen (2002) indicate that the implications of the above mentioned representations are the continued undermining of the feminine. This remains largely evident in women's participation level on socio-economic activities that present fair rewards to the general populace. Among other fields, where female participation is considerably low, that of entrepreneurship is among the leading ones. It therefore confirms that gender is a grouping factor in societies.

Schmidt and Parker (2003, p.428) outline that gender differences exist in terms of educational background, family support, attitudes, ambitions, availability of financial capital resources, networking opportunities and growth rates. Carter $(2000, p .329)$ also reveals that gender differences can be identified by comparing men to women business owners. Thus compared to males, female business owners pursue self-employment with fewer financial assets, less business related experience especially in management and under-resourced in terms of social capital. Schmidt and Parker (2003, p.433) further indicate that compared to men, women suffer from sector or industry experience, business knowledge, prior managerial experience and women are also inexperienced in marketing as well as creation of client base.

Amin and Kushnir $(2013$, p.1) indicate that gender-based inequality is neither unique to human capital nor restricted to a handful of countries. Amin and Kushnir further argue that presently, there is no country in the world that has reached equality between women and men in critical areas such as economic participation particularly through entrepreneurship. Thus, gender-based difference is statistically significant, economically large, and more distinct in smaller firms. As indicated earlier, Fapohunda $(2013$, p.36) outlines that gender differences often occur in respect of human capital and that there is a significant relationship between human capital and entrepreneurial success. Gender differences in human capital across different cultural settings are a result of expectations each society assigns as to the roles of men and women. For example, across Africa, unlike men who are expected to fulfil career-related roles, women are expected to fulfil domestic roles. In other words, social roles expectancies significantly affect various behaviours including occupational choices. To a certain degree, female entrepreneurs are perceived to possess low levels of experience which sends a signal that they may not be successful in fully exploiting emerging entrepreneurial opportunities. In the paragraphs to follow, the relationship between gender and prior business ownership experience, gender and management experience as well as gender and industry experience is discussed. 


\subsection{Gender and prior business ownership experience}

According to Dyke et al. (1992, p.73) there are two kinds of experience that relate to ownership of previous firms which are previous experience in a small business (entrepreneurial experience) and participation in previous business start-ups (start-up experience). This study however specifically focuses on previous experience in a small business (entrepreneurial experience) which is in line with the study's objectives. A significant body of research has examined the relationship between prior business ownership experience of the firm owner and subsequent firm performance (Keeley \& Roure, 1990; Stuart \& Abetti, 1990; Sandberg \& Hofer, 1987; and van de Ven et al. 1984 as cited in Reuber, 1997, p.54). However, this study intends to establish whether there a significant association can be found on prior business ownership experience between male and female SMME owners/entrepreneurs. Reuber (1997, p.54) points out that the main focus of the above mentioned studies is on prior business ownership experience because of the interest on the part of lenders and investors in being able to identify qualifying business entities before committing resources to such business entities. Dyke et al. (1992, p.72) further suggest that the relevant types of experiences could further be used as criteria in evaluating business plans or investment and loan applications, mainly as basis for tailoring development, incubation and educational programs aimed at small business owners/entrepreneurs. According to Fairlie and Robb (2008), prior business ownership experience is an important form of resource for either new or old business owners. Fairlie and Robb further note that prior business ownership experience has been found to increase the likelihood of the business owner contributing positively to favourable outcomes of his/her business entity. A study of Canadian small business entities reveals that $30 \%$ of women had previous business ownership experience compared to $57 \%$ of men (Cliff, 1998). Fairlie and Robb (2008) also support Cliff (1998) findings and indicate that, compared to female entrepreneurs, male entrepreneurs typically have had more prior experience either entrepreneurial (business ownership) or through start-ups. However, in this paper, researchers hypothesise that:

H1: No significant association can be found between gender and the level of prior business ownership experience.

\subsection{Gender and managerial experience}

According to Mohammad and Khrystyna (2013), managerial experience is an invaluable component of overall human capital of any economy. Thus, gender-based differences in managerial experience may have serious implications for gender inequality on income and employment opportunities to individuals who seek formal employment. To individuals who pursue self-employment through the operation of business entities such as SMMEs, gender disparity in management experience could also affect the firm's outcomes. To that effect, Dyke et al. (1992, p.73) posit that individuals with previous managerial experience are generally found to own more successful business entities. In addition, Amin and Kushnir (2013) point out that managerial experience is so vital to entrepreneurs/business owners for it can shed light on how to implement and prioritise policies aimed at attaining positive outcomes for a business entity. A study conducted by Berger et al. (2012), covering German banks, found that teams with more female executives tend to take more risky decisions. The empirical study further suggests that this finding is most likely due to the fact that female executives have less managerial experience than male executives. Amin and Kushnir (2013) focused on managerial experience and how it varies between female and male managers of business entities in the formal sector covering 71 developing nations. The results of the study reveal strong evidence of lower managerial experience among female managers compared to their male counterparts. Mba (2006) also support the argument by Amin and Kushnir (2013) and further indicate that female small business owners have less valuable managerial experience. Further Brush et al. (2000, p.3) suggest that gender differences especially on managerial experience render it more difficult for female entrepreneurs to make connections in order to conclude attractive entrepreneurial deals.

On the contrary, some studies however argue that female entrepreneurs have higher levels of managerial experience compared to male entrepreneurs. For example a study conducted by Birley et al. (1987, p.30) with the aim of revealing the nature of previous employment between males and females. The study reports that $49 \%$ of men compared to $55 \%$ of women classified themselves as having held a managerial position. Supporting Birley et al. (1987), Hisrich and Brush (1985) report that female entrepreneurs do possess relevant business experience especially in management. Despite the presence of studies such as Birley et al. (1987) and Hisrich and Brush (1985) who argue that, female entrepreneurs have higher levels of managerial experience compared to men, empirical evidence arguing on the contrary is overwhelming to convince a person that unlike men, women business owners possess lower levels of management experience. In this paper, researchers therefore hypothesise that:

$\mathrm{H}_{2}$ : No significant association can be found between gender and the level of managerial experience. 


\subsection{Gender and industry experience}

Dyke et al. (1992, p.73) define industry experience as prior work experience in firms which provide the same products or services as does the current firm owned by the entrepreneur. However, Dyke et al. $(1992$, p.79) find that previous experience in the industry in which the current firm operates is significantly and positively related to SMME performance. Keeley and Roure (1990) examined the effect of industry experience on a technological-based firm and van de Ven et al. (1984) also examined the effect of industry experience on an educational software firm respectively. The above studies argue that there is no significant relationship between industry experience of entrepreneurs and SMME outcomes. De Tienne and Chandler (2007, p.372) in their study test how industry experience affected opportunity identification in male and female entrepreneurs, they reveal that, for females, the number of previous jobs one had in a given industry positively predicted the number of opportunities identified. In their findings, this accounted for $20 \%$ of the variance in females compared to $5 \%$ for males. De Tienne and Chandler findings suggest that, women and men differ significantly in their level of industry experience and their application of such experience. However, Robb and Watson (2012, p.551) report that compared to male owners, female owners had less years of previous industry experience. It therefore implies that the different levels of industry experience have a significant influence on both men and women when engaging in entrepreneurial activities. Researchers therefore hypothesise that:

$\mathrm{H}_{3}$ : No significant association can be found between gender and the level of industry experience.

\section{Methodology}

The goal of this study is to investigate whether men and women entrepreneurs have different levels of business related experience and to identify which gender group overall possess higher levels of experience compared to the other. To gather primary data, researchers made use of self-administered questionnaires which were distributed to 109 sole traders (56 males and 53 women) in King William's Town, South Africa. The researchers applied quota sampling as it is used by researchers when they want a sample to be representative of certain characteristics of a study population and when they are unable to select a probability sample (Cottrell \& McKenzie, 2011, p.134). More importantly, quota samples include participants who are chosen in approximate to the population traits they are to represent. In this study, 53 women-owned SMMEs representing $48.5 \%$ of self-employed women in South Africa and 56 male-owned SMMEs represent $51.5 \%$ of self-employed men country wide (International Finance Corporation (IFC), 2006, p.5). Some researchers such as Neutens and Rubinson (2010, p.141) refer to quota sampling as "the non-probability sampling equivalent of stratified sampling." This further confirms that quota sampling method can be used when the population parameters are known and if a probability sample cannot be selected. To analyse data, descriptive statistics making use of charts was implemented. Also, the Chi-square test was carried out in testing of the study's hypotheses. A Shapiro-Wilk (1965) test ( $p>0.05)$ and a visual inspection of their histograms, normal Q-Q plots and box plots showed that the business related experience average scores were approximately normally distributed for both males and females. The Skewness and kurtosis business related experience average scores are presented in Table 1.

Table 1: Average gender Skewness and kurtosis scores

\begin{tabular}{|c|c|c|c|c|}
\hline Dependant Variable & Male Skewness & Male Kurtosis & Female Skewness & Female Kurtosis \\
\hline "business related experience" & $0.716(\mathrm{SE}=0.398)$ & $-0.224(\mathrm{SE}=0.778)$ & $0.539(\mathrm{SE}=0.414)$ & $-0.659(\mathrm{SE}=0.809)$ \\
\hline
\end{tabular}

According to Razali and Wah (2011), if the ratio of Skewness and kurtosis to their respective standard errors (SE) is not within the range of -1.96 to +1.96 , the data are probably not normally distributed. The ratios of Skewness and kurtosis to their respective standard errors have been calculated and all values fall within the gazetted range suggesting that the data is approximately normally distributed.

\section{Results and Discussion}

Based on a $64 \%$ survey response rate, the study's results are outlined in the paragraphs to follow, beginning with the respondents' education level. 


\subsection{Respondents' education level}

Education level information is vital especially as it provides information with regards to respondents' qualifications in relation to gender and their involvement in entrepreneurial activities. Results are outlined in Table 2.

Table 2: Respondents classification by education level

\begin{tabular}{|c|c|c|c|c|c|c|c|c|}
\hline \multirow{2}{*}{ Gender } & \multicolumn{7}{c|}{ Education level } & \\
\cline { 2 - 9 } & Some high school & Completed high school & Some College & Completed College & Some graduate work & A graduate degree & Total \\
\hline Male & 0 & 4 & 2 & 4 & 7 & 19 & 36 \\
\hline Percent & 0 & 11.11 & 5.56 & 11.11 & 19.44 & 52.78 & 100 \\
\hline Female & 1 & 9 & 0 & 4 & 9 & 11 & 34 \\
\hline Percent & 2.94 & 26.47 & 0 & 11.76 & 26.47 & 32.35 & 100 \\
\hline
\end{tabular}

From the results, approximately 53\% male SMME owners compared to $32 \%$ female SMME owners indicated attaining a graduate degree. More women (26.47\%) compared to men (19.44\%) SMME owners are pursuing self-employment either as university students. Of the surveyed SMME owners, $11.11 \%$ men and $11.76 \%$ women had completed college and $5.56 \%$ male SMME owners were studying towards some college education. Amongst those who indicated high school as their highest education level, more female SMME owners (26.47\%) compared to men (11.11\%) had completed high school education and only $2.94 \%$ of the female SMME owners had not completed high school education. On the other hand, results reveal that none of male entrepreneurs were operating small business enterprises without completing high school education. The results are consistent with findings by the Global Entrepreneurship Monitor (2013:22). GEM, (2013:22) reports that the lowest level of education can be found in Sub-Saharan Africa, where an average of $42 \%$ of women business owners have at least a secondary (high school) degree and 15\% have a post-secondary degree (college) or higher. In addition, women business owners in Sub-Saharan Africa are more likely to be secondary or postsecondary graduates than non-business owners. In consistency with this study, the GEM, (2013:22) concludes that the level of education for women in Sub-Saharan Africa is lower than that of their male counterparts.

\subsection{Gender and managerial experience}

A gender and managerial experience cross tabulation was carried out in order to establish the level of managerial experience between the groups. Figure 1 reveals the cross tabulation results in a bar chart format.

Figure 1: Classification of respondents by managerial experience

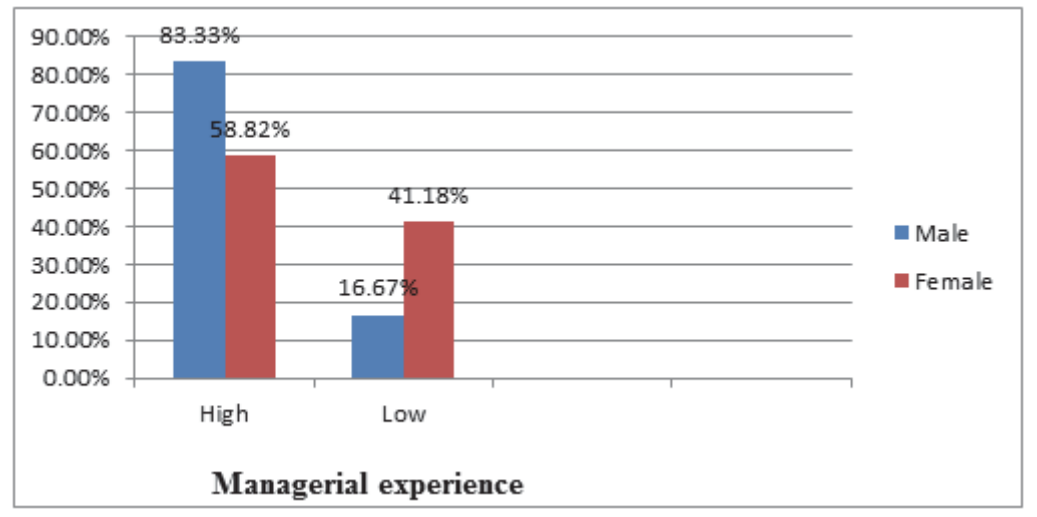

Results reveal that, $83.33 \%$ male SMME owners compared to $58.82 \%$ female SMME owners had high managerial experience. Thus, prior to owning the current business, $83.33 \%$ men compared to $58.82 \%$ women had managerial responsibilities in two previous recent positions. Thus, male SMME owners outrank their female SMME owner 
counterparts in the high managerial experience category. On the other hand, $41.18 \%$ female SMME owners compared to 16.67\% male SMME owners reported having no prior managerial responsibilities in two previous recent positions. Thus, female SMME owners recorded the highest score in the low level managerial experience category represented by $41.18 \%$ compared to their male counterparts who recorded $16.67 \%$. The findings of the study are consistent with the findings of a study conducted by Amin and Kushnir, (2013). Amin and Kushnir focused on managerial experience and how it varies between female and male owner/managers of small and large business entities in the formal sector covering 71 developing nations. In their study, they report finding strong evidence of lower managerial experience among female owner/managers compared to their male counterparts.

\subsection{Gender and industry experience}

Gender and industry experience cross tabulation was performed in order to identify the level of industry experience between male and female SMME owners. Figure 2 reveals the classification of respondents by industry experience cross tabulation results in a bar chart format.

Figure 2: Classification of respondents by industry experience

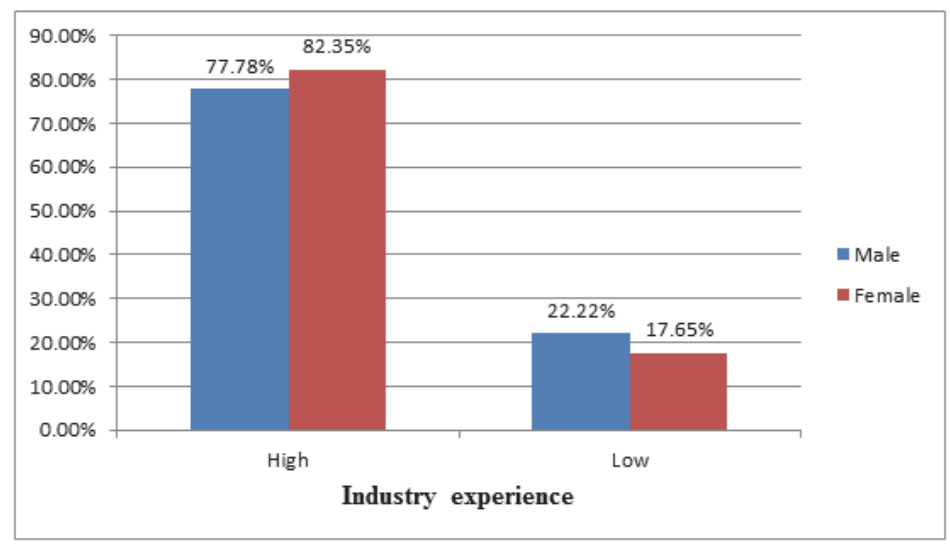

With regards to industry experience, it can be observed that in the high category, female SMME owners represented by $82.35 \%$ outrank their male counterparts (77.78\%). Thus, prior to owning the current business enterprise, $82.35 \%$ female SMME owners had worked in a business as they currently own compared to $77.78 \%$ male SMME owners. On the other hand, the low industry experience category is dominated by male business owners who recorded $22.22 \%$ compared to female business owners who recorded $17.65 \%$. Thus, $22.22 \%$ male SMME owners compared to $17.65 \%$ female SMME owners, prior to owning the current business enterprise had neither worked in a similar business enterprise. For example, given that an SMME owner, owns a construction company, to be considered as possessing industry experience he/she will have worked in a construction industry before running a construction firm. The study findings in relation to industry experience between genders dispute the findings of Robb and Watson, (2012:551) as well as Decheneaut, (1997). According to Ducheneaut, (1997), in France, 54\% of women business owners have some industry experience compared to $70 \%$ of men. In support to this notion, Robb and Watson, (2012:551) state that compared to male owners, female owners had less years of previous industry experience and this difference is likely to disadvantage female firm owners in self-employment.

\subsection{Gender and prior business ownership experience}

The other cross tabulation was performed with regards to gender and prior business ownership experience. This was also done in order to establish the level of prior business ownership experience between the groups. Figure 3 reveals the cross tabulation results also in a bar chart format. 
Figure 3: Classification of respondents by prior business ownership experience

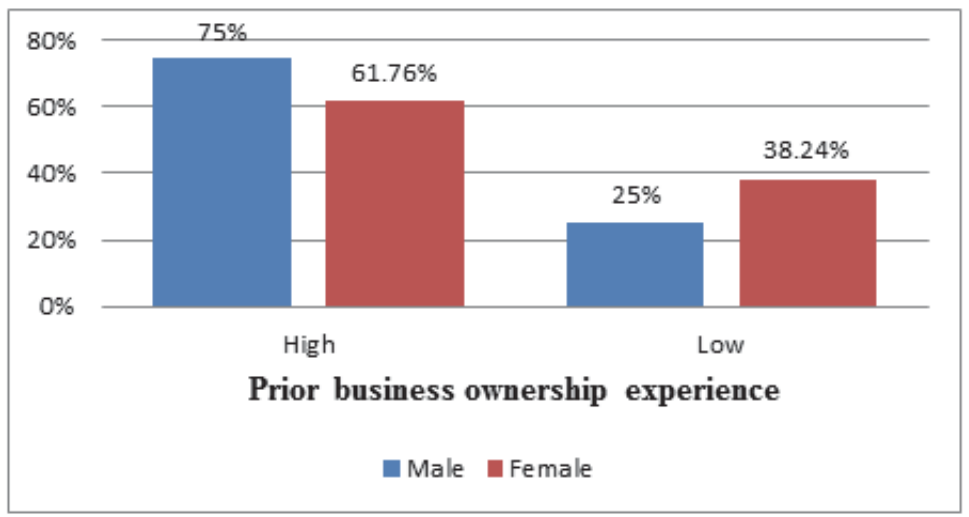

The results reveal that male SMME owners represented by $75 \%$ outrank female SMME owners in prior business ownership experience represented by $61.76 \%$. In other words, prior to owning the current business enterprise $75 \%$ male business owners, compared to $61.76 \%$ female business owners, had either owned a firm just similar or not necessarily similar to the one they currently own. On the other hand, $25 \%$ of male business owners compared to $38.24 \%$ female business owners had neither owned a firm just similar or not necessarily similar to the one they currently own. Thus, male SMME owners outrank their female counterparts in prior business ownership experience. The study findings are consistent with the findings of Cliff, (1998) and Fairlie and Robb, (2008). In a study of Canadian small business entities, Cliff (1998) reveals that $30 \%$ of women had previous business ownership experience compared to $57 \%$ of men. On the other hand, Fairlie and Robb, (2008) indicate that, compared to female business owners, male business owners typically have had more prior experience either entrepreneurially (business ownership) or through start-ups. Taking into consideration this empirical finding with regards to business related experience indicators (managerial, industry and prior business ownership) between genders, the findings suggests that on average, male SMME owners possess high business related experience compared to female SMME owners.

\subsection{Hypotheses testing}

The Chi-square test was carried to test the study's hypotheses and overall results are outlined in Table 3.

Table 3: Chi-square test results

\begin{tabular}{cccc}
\hline Hypotheses & p-value & Df & $\boldsymbol{X}^{2}$ \\
\hline $\mathrm{H}_{1}$ & 0.023 & 1 & 5.147 \\
$\mathrm{H}_{2}$ & 0.632 & 1 & 0.229 \\
$\mathrm{H}_{3}$ & 0.002 & 1 & 9.651 \\
\hline
\end{tabular}

Results from Table 3 suggests that there is ground to reject $\mathrm{H} 1$ and $\mathrm{H} 3$ concluding that a significant association can be found between gender and the level of managerial and as well as between gender and the level of prior business ownership experience. However, results further suggest that there is no evidence to reject the null hypothesis which states that no significant association can be found between gender and the level of industry experience. The study's findings support the conclusions of the Eurostat (2008) stating that as far as prior business ownership is concerned, when compared to male entrepreneurs; female entrepreneurs possess low levels of experience. The Eurostat reveal findings across 15 European countries pointing out that approximately 11.2\% female entrepreneurs/business owners compared to $18.4 \%$ male entrepreneurs/business owners who undertook new venture start-up in the year 2002 had owned other entrepreneurial enterprises before. The U.S., statistics as of the year 2007 with regards to previous self-employment (as a small or large business owner) reveal that male business owners had more experience compared to female business owners represented by $42 \%$ and $28 \%$ respectively (U.S. Census, 2009). Furthermore, Jung (2010) concurs with the study 
findings and reveals that in 2007, " $51 \%$ of female owners of small and medium-sized enterprises in Canada had more than ten years of management as well as ownership experience compared to $74 \%$ of their male counterparts."

\section{Conclusion and Recommendations}

Catalyst (2007) indicate that in various studies, Fortune 500 firms with more women board directors are shown to have significantly better financial performance, including $53 \%$ higher returns on equity, $42 \%$ higher returns to sales and $66 \%$ higher returns on invested capital. The London Business School (LBS) (2007a) reports that more women in managerial teams have been found to increase the innovation capacities of firms. In addition, McKinsey and Company (2007) report in an international study of large corporations, those with a higher proportion of women in top management demonstrated the best performance in terms of work environment, innovation, accountability and profits. Given this background, we therefore conclude that business related experience is critical in both men and female SMME owners. In order to increase the number of female managers, consequently increasing the number of female entrepreneurs with managerial experience as well as industry experience in case they consider self-employment in the near future, requires a combined effort from the public sector, private sector and the general stakeholders.

It should however be noted that increasing the number of women managers can be tackled like any other management challenge by setting clear goals and targets, as well as monitoring results and rewarding progress both in private and public sector. The London Business School (LBS) (2007b) indicate that a survey of corporate best practice in Europe found that $27 \%$ of leading firms set targets for the number of women in senior executive roles. The public service and the private sector in South Africa and also other countries within the region facing the same predicament, can as well adopt the same measure. Academics and legislators can also influence the responsible authorities to adopt the Norwegian government style. In the year 2003, an Act of Law directed to firms trading on the stock exchange was passed. The Act strictly requires that for each publicly-listed firm's board of directors, at least $40 \%$ should be women. This explains why Norway as a country leads the world in the number of female directors and female entrepreneurs with managerial experience and probably industry experience as well. Renowned global networks, the likes of World Association of Women Entrepreneurs (FCEM), do play a major role in in the sharing and transfer of business related experience between countries (OECD, 2012, p.282). It is of high importance that female entrepreneurs do associate with such organisations as they may stand to benefit from their experiences and different expertise. The OECD further underline that "many top performing women entrepreneurs in growth-oriented" enterprises "have senior management experience in companies, where they gained experience in industry and leadership." This enabled them to have access to valuable networks which they constantly utilise to the success of their privately owned firms. This study concludes that an improved gender balance in business related experience can thus have important "spill over" effects on female entrepreneurs. Future research can be carried out to examine how gender differences in business related experience influence firm performance. Also future research can be carried out to ascertain the role of business relevant experience (if any) between genders on SMMEs access to financial resources such as debt and venture capital.

\section{References}

Amin, M. and Kushnir, K. 2013. Gender Disparity in Human Capital: Going Beyond Schooling. Mimeograph. [Online]. Available http://works.bepress.com/mohammad_amin/46/. [Accessed: 15 September 2013].

Baum, J.A.C. and Silverman, B.S. 2004. Picking Winners or building them? Alliance, intellectual, and human capital as selection criteria in venture financing and performance of biotechnology start-ups. Journal of Business Venturing, №. 19, pp. 411-436.

Becker, G.S. 1964. Human capital. Columbia University Press, New York.

Berger, N.A., Kirk, T. \& Schaeck, K. 2012. Executive Board Composition and Bank Risk Taking. Discussion Paper No. 03/2012, Deutsche Bundesbank.

Birley, S., Moss, C. and Saunders, P. 1987. Do women entrepreneurs require different training? American Journal of Small Business. [Online]. Available: https://dspace.lib.cranfield.ac.uk/retrieve/805/SWP5087.pdf. [Accessed: 12 September 2013].

Bosma, N.S. Van Praag, C.M., Thurik, A.R. and De Wit, G. 2004. The value of human and social capital investments for the business performance of start-ups. Small Business Economics, No. 23, pp. 227-236.

Brush, C., Carter, N., Greene, P., Hart, M. and Gatewood, E. 2000. Women and equity capital: An exploration of factors affecting capital access. Frontiers in Entrepreneurship, Proceedings from the 12th Annual Entrepreneurship Research Conference, ARTHUR M. BLANK Center for Entrepreneurship, Babson College, Massachusetts 02457-0310. [Online]. [Available: http://www.babson.edu/entrep/fer/TOC/TOC.html. [Accessed: 12 September 2013].

Brush, C.G., Greene, P.G. and Hart, M.M. 2001. "From initial idea to unique advantage: The entrepreneurial challenge of constructing a resource base." Academy of Management Executive, Vol. 15, No.1, pp. 64-78.

Carter, S. 2000. Improving the numbers and performance of women-owned businesses: Some implications for training and advisory 
services. Education and Training. Vol. 42. Nos. 4/5 pp. 326-34.

Cassar, G. 2006. "Entrepreneur opportunity cost and intended venture growth." Journal of Business Venturing, No. 21, pp. 610-632.

Catalyst. 2007. The Bottom Line: Corporate performance and women's representation on boards.

Cliff, J.E. 1998. Does one size fit all? Exploring the relationship between attitudes to growth, gender and business size. Journal of Business Venturing, Vol. 13, pp. 523-542.

Cottrell, R.R. \& McKenzie, J.F. 2011. Health promotion and education research methods: Using the five-chapter thesis/dissertation model. $2^{\text {nd }}$ Edition. [Online]. Available: http://books.google.co.za/books?id=6LrJNCrTf9EC\&pg=PA134\&dq=quota+sampling+ and+quantitative+studies\&hl=en\&sa=X\&ei=B_wVUvjmEYaphAeBj4CoAw\&ved=0CD0Q6AEwAg\#v=onepage\&q=quota\%20sampl ing\%20and\%20quantitative\%20studies\&f=false. [Accessed: 22 May 2014].

Crannie-Francis, A., Waring, W., Stavropoulos, P. and Kirky, J. 2003. "Terms and debates." Basingstoke: Palgrave.

De Tienne, D.R. and Chandler, G.N. 2007. The role of gender in opportunity identification. Entrepreneurship, Theory and Practice, Vol. 31, No. 3, pp. 365-386.

Ducheneaut, B. 1997. "Women entrepreneurs in SMEs." Report prepared for the OECD conference on Women Entrepreneurship in Small and Medium Sized Enterprises: A major force for Innovation and job creation. Paris, France: OECD.

Dyke, L.S., Fischer, E.M. And Reuber, A.R. 1992. An inter-industry examination of the impact of owner experience on firm performance. Journal of Small Business Management, No. 30, 72-87.

Ethical Investment Research Services (EIRIS). 2005. How global is good corporate governance?

Eurostat. 2008. "Statistics explained: factors of business success survey, Luxembourg." [Online]. Available: http://epp.eurostat.ec. europa.ec/statistics_explained/index.php/Factors_of_business_success [Accessed: 6 March 2014].

Fairlie, R.W. and Robb, M. 2008. Race and entrepreneurial success: Black, Asian-, and White-owned Businesses in the United States. Cambridge: MIT Press.

Fapohunda, T.M. 2013. Gender differences in human capital and personality traits as drivers of gender gap in Entrepreneurship: Evidence from Nigeria. British Journal of Economics, Management and Trade, Vol. 3. No. 1, pp. 30-47.

Frese, M., Krauss, S.I., Keith, N., Escher, S., Grabarkiewicz, R., Luneng, S.T., Heers, C., Unger, J.M. and Friedrich, C. 2007. "Business Owners' Action Planning And Its Relationship To The Business Success In Three African." Journal Of Applied Psychology, Vol. 92, No. 6, pp. 1481-1498.

Global Entrepreneurship Monitor. 2013. Global Entrepreneurship Monitor 2012 women's report. [Online]. Available: http://www.GEM\%2012\%women\%report.pdf [Accessed: 13 February 2014].

Gutek, B. and Cohen, A. 1992. "Sex ratios, sex spill over and sex at work," In A. Mills \& P. Tancred (Eds.). "Gendering organisational analysis." London: Sage.

Harber, S. and Reichel, A. 2007. The cumulative nature of the entrepreneurial process: the contribution of human capital, planning and environmental resources to small venture performance. Journal of Business Venturing, No. 22, pp. 119-145.

Hisrich, R.D. And Brush, C. 1985. "Women and minority entrepreneurs: A comparative analysis." Frontiers of entrepreneurship research, pp. 566-587.

Honig, B. 2001. Human capital and structural upheaval: a study of manufacturing firms in the West Bank. Journal of Business Venturing, No. 16 , pp. $575-594$

Honig, B. And Davidsson, P. 2003. "The role of social and human capital among nascent entrepreneurs." Journal of Business Venturing, No. 18, pp. 301-331.

International Finance Corporation. 2006. "Diagnostic Study On Access To Finance For Women Entrepreneurs In South Africa." [Online]. Available: Http://Www.Ifc.Org/Gem/Southafrica_Women_Fullreport.Pdf. [Accessed: 05 June 2014].

Jung, O. 2010. Women entrepreneurs. Small Business Financing Profiles. Industry Canada.

Keeley, R.H. and Roure, J.B. 1990. Management strategy and industry structure as influences on the success of new firms. Journal of Management Sciences, Vol. 36. No. 10, (1990).

Lister, R. 2003. "Citizenship, feminist perspectives." Houndmills: Palgrave.

London Business School. 2007a. Innovative potential: Men and Women in teams.

London Business School. 2007b. Inspiring women: Corporate best practice in Europe.

Marlow, S. and Patton, D. 2005. "All credit to men? Entrepreneurship, finance, and gender." Entrepreneurship Theory and Practice, pp. 717-735.

Mba, N. 2006. Women and politics in colonial Nigeria. Paper presented at the symposium on the impact of colonialism on Women in Nigeria Women's Research Documentation Centre, Institute of African Studies, University of Ibadan Oct. pp. 16-18.

McKinsey and Company. 2007. Women matter: Gender diversity, a corporate performance driver, Mckinsey \& Company. [Online]. Available: http://www.mckinsey.com/features/women_matter [Accessed: 7 January 2014]

Mincer, J. 1974. Schooling, experience and earnings. Columbia University Press: New York.

Mohammad, A. and Khrystyna, K. 2013. "Gender Based Differences in Managerial Experience: The Case of Informal Firms in Rwanda." Mimeograph. [Online]. Available at: http://works.bepress.com/mohammad_amin/48. [Accessed: 15 September 2013].

Neutens, J.J. and Rubinson, L. 2010. "Research Techniques For The Health Sciences." $4^{\text {th }}$ Edition. San Francisco: Benjamin Cummings. Oakley, A. 1972. "Sex, gender and society." London: Temple Smith.

Organisation for Economic Cooperation and Development (OECD). 2008. Gender and sustainable development: Maximising the economic, social and environmental role of women. [Online]. Available: http://www.oecd.org/social/40881538.pdf. (Accessed: 05 March 2014). 
Organisation for Economic Cooperation and Development (OECD). 2012. Closing the gender gap: Act now. OECD Publishing. [Online]. Available: http://dx.doi.org/10.1787/97892264179370. (Accessed: 6 March 2014).

Powell, G.N., Kimberly, A. and Eddleston, A. 2008. The Paradox of the Contented Female Business Owner. Journal of Vocational Behaviour, 73: 24-36.

Razali, N.M. and Wah, Y.B. 2011. "Power comparisons of Shapiro-Wilk."

Reuber, R. 1997. Management experience and management expertise. Journal of Decision Support Systems, 21: 51-60.

Robb, A.M. and Watson, J. 2012. Gender differences in firm performance: Evidence from new ventures in the United States. Journal of Business Venturing, No. 27, pp. 544-558.

Sandberg, S.R. and Hofer, C.W. 1987. Improving new venture performance: the role of strategy, industry structure and the entrepreneur. Journal of Business Venturing, No. 2. (1987).

Schmidt, R.A. and Parker, C. 2003. Diversity in independent retailing: barriers and benefits - the influence of gender. International Journal of Retail \& Distribution Management, Vol. 31. No. 8, pp. 428-439.

Schultz, T. 1959. Investment in man: An economist view. Social Service Review, 33(2): 69-75.

Shane, S. and Venkatraman, S. 2000. "The promise of entrepreneurship as a field of research." Academy of Management Journal, No. 25, pp. 217-226.

Shapiro, S.S. and Wilk, M.B. 1965. "An analysis of variance test for normality." "(Complete Samples)." Biometrika, Vol. 52, No. 3/4, pp. 591-611.

Sonnentag, S. and Frese, M. 2002. Performance concepts and performance theory. In: Sonnentag, S. (Eds.). Psychological Management of Individual Performance: A Handbook in the Psychology of Management in Organisations. Wiley, Chichester, pp. 3-25.

Stuart, R.W. and Abetti, P.A. 1990. Impact of entrepreneurial and management performance on early performance. Journal of Business Venturing, Vol. 5. No. 3, (1990).

Synnot, A. 1993. "The body social: Symbolism, self and society." London: Routledge.

Tradennick, H. 1968-1969. "Aristotle: The metaphysics." London: Heinemann.

U.S. Census. 2009. "Results from the 2007 Survey of Business Owners." [Online]. Available: http://www.census.gov/econ/sbo/ [Accessed: 6 March 2014].

Unger, J.M., Rauch, A., Frese, M. and Rosenbusch, N. 2009. Human capital and entrepreneurial success : A meta-analytical review. Journal of Business Venturing, Vol.26. No. 2011, pp. 341-358.

Van De Ven, A., Hudson, R. and Schroeder, D.M. 1984. Designing new business start-ups: entrepreneurial, organisational, and ecological considerations. Journal of Management, Vol. 10. No. 1, (1984).

Zacharakis, A.L. and Meyer, D.G. 2000. The potential of actuarial decision models: Can they improve the venture capital investment decision? Journal of Business Venturing, No. 15, pp. 323-346. 